Information and Communication Technology Competencies Required of Business Educators...

\title{
References
}

Carrilo, I.J. (1999). The Knowledge management movement: current derives and future scenarioe. ITESM: Centre for Knowledge system.

Cheung, C. K. (1998). Business Education in Hong Kong after 1997. Journal of Education for Business 73 (6) 333-335.

Dolar, R.T.F. and Wilson, O.O. (2005). Consumer satisfaction with GSM service in Warri metropolis. Business Education Journal 5 (1) 6872 .

Federal Republic of Nigeria (FRN, 2004). National Policy on Education. Lagos: NEDRC.

Ile, C.M. (2005). Competencies needed by business education graduates to survive in advanced information age. Business Education Journal 4 (1) $77-83$.

Kutelu, Oladepo, Adalu, George and Udensi, C. (Jan. 25, 2006). Negative effects of Internet. Daily Sun pp. 21.

Laudon, K.C. and Laudon, J.P. (2002). Management information systems. New Hersey: Prentice-Hall Inc.

Leon, J. and Leon K, L. (1999). Enhancing business school effectiveness. American management Association. 65(4) 135-138.

Morrison, J.L. (1998). Power learning in digital age: bring reality to the discipline. Journal of Education for Business 73 (5) 261-263.

National Commission for Colleges of Education (NCCE, 2002). Minimum Standard for NCE teachers. ( $3^{\text {rd }}$ ed.) Abuja: NEDRC.

Nwachokor, J. O. and Akume, B.C. (2005). Ethical and moral dimension of information and communication technology. Business Education Book of Readings I (5) 89-91.

Nwosu, A. N. (1999). Training and developing business educators as a coping strategy for the emerging technological innovations in secretarial education. Business education journal 3(2) 40-46.

Okereke, E. (2006). Handbook on computer engineering. IMSU, Onitsha Information center. 
Patrum, J. K. (2002). Teacher and information technology. Training Leadership 83 (2) 54-56.

Thomas, R. (2006). Life online: the web in 2020 A; a study by the social issues - research center. http://www.orgn/publik/2020.pdf.

Umezulike, A. N. (1997). Accounting teachers' perceptions of the problems of teaching accounting at the public secondary in Onitsha North Education Zone. Unpublished degree thesis, Nnamdi Azikiwe University, Awka.

Table 1: Mean Ratings of ICT Competencies Required of Business Educators Them in Teaching Business Education Courses for the Actualization of Vision 2020 Agenda

\begin{tabular}{llll}
\hline Items & $\begin{array}{l}\text { ICT Competencies required to business } \\
\text { teachers }\end{array}$ & $\mathbf{X}$ & Decision \\
\hline 1. & $\begin{array}{l}\text { Ability to understand computer language } \\
\text { 2. }\end{array}$ & 4.23 & Accept \\
& $\begin{array}{l}\text { Knowledge of various computer } \\
\text { equipment and programme applications }\end{array}$ & 3.92 & Accept \\
3. & $\begin{array}{l}\text { Ability to manipulate the computer } \\
\text { keyboard }\end{array}$ & 4.50 & Accept \\
4. & $\begin{array}{l}\text { Knowledge of protocols in the internet } \\
\text { 5. }\end{array}$ & $\begin{array}{l}\text { Ability to analyse information and make } \\
\text { appropriate decisions. }\end{array}$ & Accept \\
6. & $\begin{array}{l}\text { Ability to develop constructive thinking } \\
\text { and problem solving skills }\end{array}$ & 3.50 & Accept \\
Ability to understand global, national and \\
local trends
\end{tabular}


Table 2: Mean Rating of ICT Gadgets/facilities Considered Appropriate for Teaching Business Education Courses in Order to Attain the Vision 2020 Agenda.

\begin{tabular}{llll}
\hline Items & ICT Gadgets/Facilities & $\mathbf{X}$ & Decision \\
\hline 11 & Micro computer & 4.56 & Accept \\
12. & Digital Telephone/GSM & 4.26 & Accept \\
13. & Computer networking (internet/Browsing) & 3.65 & Accept \\
14. & Word processing machine & 3.86 & Accept \\
15. & Scanning machine & 3.50 & Accept \\
16. & Desktop printing & 4.56 & Accept \\
17. & Photocopiers & 3.96 & Accept \\
18. & Dictating machine & 3.24 & Reject \\
19. & Facsimile machine & 3.50 & Accept \\
20. & Voice messaging system (VMS) & 3.02 & Reject \\
21. & Bulletin Board & 3.52 & Accept \\
22. & Mobile web and interfaces & 3.00 & Reject \\
23. & Asynchronous Java scrap \& SML (AJAX) & 3.05 & Reject \\
24. & Web 2.0 & 2.95 & Reject \\
\hline
\end{tabular}


Table 3: Business Teachers' Perceptions of the Possible Problems that could Hinder the Use of ICT Gadgets/facilities in Teaching Business Education Courses

\begin{tabular}{|c|c|c|c|}
\hline Items & Problems associated with ICT usage & $\bar{x}$ & Decision \\
\hline 25. & $\begin{array}{l}\text { Non availability of ICT spare parts/poor } \\
\text { maintenance culture }\end{array}$ & 3.65 & Accept \\
\hline 26. & None availability of computers & 4.63 & Accept \\
\hline 27. & $\begin{array}{l}\text { Inadequate number of business teachers } \\
\text { with ICT knowledge (manpower) }\end{array}$ & 3.85 & Accept \\
\hline 28. & Inadequate power supply & 4.55 & Accept \\
\hline 29. & Insufficient teaching periods. & 3.50 & Accept \\
\hline 30. & High cost of ICT equipment & 3.87 & Accept \\
\hline 31. & Non provision of retraining programme. & 3.22 & Reject \\
\hline 32. & $\begin{array}{l}\text { Poor funding on the part of the } \\
\text { government. }\end{array}$ & 3.75 & Accept \\
\hline 33. & Poor network service. & 3.99 & Accept \\
\hline 34. & $\begin{array}{l}\text { High rate of criminal manipulation in } \\
\text { using internet services }\end{array}$ & 3.58 & Accept \\
\hline
\end{tabular}

Table 4: T-Test Analysis at 0.05 Level of Significance of Business Teachers Regarding ICT Competencies Required of Them for the Actualization of Vision 2020 Agenda

\begin{tabular}{lccccccc}
\hline $\begin{array}{l}\text { Business } \\
\text { educators }\end{array}$ & & $\mathbf{x}$ & $\mathbf{S}^{2}$ & $\mathbf{D f}$ & T-cal. & T-crit. & Decision \\
\hline Universities & 12 & 3.81 & 0.64 & & & & \\
& & & & 54 & 0.73 & 1.64 & Accepted \\
$\begin{array}{l}\text { Colleges of } \\
\text { Education }\end{array}$ & 44 & 3.62 & 0.81 & & & & \\
\hline
\end{tabular}




\title{
African Research Review
}

An International Multi-Disciplinary Journal, Ethiopia Vol. 3 (5), October, 2009

\section{The Pedagogical Implications of Information and Communication Technology on Adult Education: A Case Study of the Osun State Colleges of Education, Nigeria}

Bada, Tayo A. - Department of Educational Technology, Faculty of Education, Obafemi Awolowo University, Ile-Ife E-mail: badatayo2@yahoo.com

Adekomi, Abimbola A - Department of Educational Technology, Faculty of Education, Obafemi Awolowo University, Ile-Ife

Oluwatosin, Sehinde.A. - Department of Educational Foundations and Counselling, Faculty of Education, Obafemi Awolowo University, Ile -Ife

\begin{abstract}
It is known that teaching entails systematic presentation of facts, ideas, skills, and techniques to students; therefore, the introduction of technology into adult learning means more than just making it works. This research work therefore seeks to find out the pedagogical implication of Information and Communication Technology (ICT) on Adult Education in Osun State College of Education, Nigeria. One hundred (100) lecturers and one hundred (100) students of Osun State College of Education were used for the study. The instruments used for this study are questionnaires, drawn up based on the research questions. Results revealed that most of ICT facilities for teaching and learning are not available and that the attitude of lecturers and students towards the use of ICT in teaching and learning is good and positive. In addition, lecturers are also aware of the importance of using ICT in teaching and learning. Results also showed that the funding and supply of ICT facilities to departments are insufficient. From the results, the study
\end{abstract}


recommended among others, that government should endeavour to supply necessary funds for the acquisition of relevant ICT equipments. In-service computer training should be given to all the staff including the management. Finally, the department should give individual students access to the use of $1 C 1$ equipment.

Key words: Pedagogy, Adult Education, Andragogy

\section{Introduction}

ICT has opened up many opportunities, of which adult learning is not an exception.It encompasses any medium to record information (whether magnetic disk/tape, optical disks - CD/DVD, flash memory etc.); technology for broadcasting information( radio, television); and technology for communicating through voice and sound or images (microphone, camera, loudspeaker, telephone to cellular phones).At present, it is apparently culminating to information communication with the help of personal computers (PCs) networked through the internet through information technology that can transfer information using satellite systems or intercontinental cables.

The computer is an indispensable electronic gadget that has crept into virtually all the endeavours of man. Historically, computing began with an analog machine. The most important early computing instrument is ABACUS, which has been known and widely used for more than 2000 years. In 1623, German scientist Wilhelm Schikard invented a machine that used 11 complete and 6 incomplete sprocket wheels that could add, and with the aid of logarithm tables, multiply and divide. With modifications and improvements, we have what is today known as Personal Computer (PC).

PCs have revolutionized entertainment, science, the media, art, medicine, education, and business because they provide computational abilities at low cost to people with no extensive programming experience. Computer programmes, or applications, exist to aid every level of education, from programmes that teach simple addition or sentence construction to programmes that teach advanced calculus (mathematics). Educators use computers to track grades and communicate with students; with computercontrolled projection units, they can add graphics, sound, and animation to their communications.

According to Adekomi (2007) Information Communication Technology (ICT) has become a kind of a hub for communicating information, most often 
using computers. With ICT a lot of achievements have been made and these achievements have been intuitively explored, utilized and incorporated into most part of the world's educational system. Paterson 1979 said that 'adult' is multi-faceted and multifarious and different societies and cultures have contrasting understanding of what it is to be adult. According to him, adults are older than children and with this come a set of expectations. They are not necessarily mature. 'But they are supposed to be mature, and it is on this necessary supposition that their adulthood justifiably rests'. Adulthood can be defined in terms of biology, psychological adult development, law, personal character, or social status.

These different aspects of adulthood are often inconsistent and contradictory. A person may be biologically an adult, and have adult behavioural characteristics but still be treated as a child if they are under the legal age of majority. Conversely one may legally be an adult but possesses none of the maturity and responsibility that define adult character. Paterson (2008) however concluded that some qualities that symbolize adulthood in most cultures include self-control, stability, independence, seriousness, responsibility, endurance, experience, objectivity, and decision making capability.

"Adult education denotes the entire body of organized educational processes, whatever the content, level and method, whether formal or otherwise, whether they prolong or replace the initial schools, colleges, and universities, as well as an apprenticeship, whereby persons regarded as adults by the societies to which they belong develop their abilities, enrich their knowledge, improve their technical or professional qualifications which in turn brings about improved changes in their attitudes or behavior."(UNESCO: 1976). Pedagogy (ped-e-go'je) literally means the art and science of educating children and often is used as a synonym for teaching (Adekomi, 2006). More accurately, pedagogy embodies teacher-focused education. In the pedagogic model, teachers assume responsibility for making decisions about what will be learned, how it will be learned, and when it will be learned. Teachers are the ones who direct learning. In other words pedagody is the art or science of being a teacher. It is the field of study that deals mainly with methods of teaching and learning in schools. It is also sometimes referred to as the correct use of teaching strategies. For example, Paulo Frerie (1985) referred to his method of teaching as "critical pedagogy". Adult education is a domain in the educational sector which has so many tentacles and focus areas. Some of its identified areas of focus include adult literacy, continuing education, 
vocational and, Technical Skills Development, vocational and Technical Skills Development, employee Skills Development, civic Education, health Education/HIV/AIDS, Information, Communication and Technology and agricultural education.

According to UNESCO (1976), adult education is whatever education anybody, regarded as an adult, can access. In an attempt to formulate a comprehensive adult learning theory, Knowles, in 1973, published the book. The Adult Learner: A Neglected Species. Building on the earlier work of Lindeman, Knowles asserted that adults require certain conditions to learn. $\mathrm{He}$ borrowed the term, andragogy (and-re-goje) to define and explain the conditions. Andragogy, initially defined as "the art and science of helping adults learn," has taken on a broader meaning since Knowles' first edition. The term currently defines an alternative to pedagogy and refers to learnerfocused education for people of all ages. The andragogic model asserts that five issues be considered and addressed in formal learning. They include (1) letting learners know why something is important to learn, (2) showing learners how to direct themselves through information, and (3) relating the topic to the learners' experiences. (4) that people will not learn until they are ready and motivated to learn. Often this (5) requires helping them overcome inhibitions, behaviors, and beliefs about learning. Unfortunately, andragogy usually is cited in education texts as the way adults learn. Knowles himself concedes that four of andragogy's five key assumptions apply equally to adults and children. The sole difference is that children have fewer experiences and pre-established beliefs than adults and thus have less to relate. In the information age, the implications of a move from teachercentered to learner-centered education are staggering. Postponing or suppressing this move will slow our ability to learn new technology and gain competitive advantage. How can we expect to analyze and synthesize so much information if we turn to others to determine what should be learned, how it will be learned, and when it will be learned? Though our grandchildren or great-grandchildren may be free of pedagogic bias, most adults today are not offered that luxury. To succeed, we must unlearn our teacher-reliance. We must take it upon ourselves to meet our learning needs and demand training providers to do the same. To know our demands, we must know how we process information.

The most significant trend that continues to make an impact on facilitators is the demand for the incorporation of technology into the content and delivery of professional development (King, 2003). Teaching and learning with 
Technology helps facilitators (adult educators) take advantage of information technology to enrich the educational experience of their clients (students). This is designed to support and promote creative and innovative uses of technology in courses to actively engage learners in acquiring and assimilating the core principles and experiences of a discipline. Teaching and learning with technology can be both challenging and engaging for instructors and students.

Technologies make it easier for instructors to create learning opportunities, provide prompt feedback, and improve student engagement with content materials. Introducing technology into the curriculum means more than just "making it work." The principles of adult learning theory can be used in the design of technology-based instruction to make it more effective. Malcolm Knowles' theory of andragogy allows teacher/facilitators to structure lessons which are part of a relevant learning environment for adult students.

Information and Communication Technologies present a range of tools that can be used by teachers to present and demonstrate as part of their teaching as well as something for learners to use as part of an activity as individuals or in groups. These technological tools can be explicitly designed for use in educational contexts. The choice of when and how to use such technologies in teaching and learning is complex knowledge of, and experience with computers is not enough to enable teachers to make the best use of IT. Effective adoption of computers within the classroom takes time, even up to a year with the support of an experienced team or through collaborative working (Sandholtz, 2001). In addition, the way in which teachers' skills, beliefs and practices are related is complex and this in turn affects the way that teachers choose to use ICT and how effective they are at using it (Higgins and Moseley, 2001).

\section{Research Questions}

Based on the above problems, the following questions were raised:

(1)Which of these ICT facilities are available for teaching and learning in Nigerian institutions?

(2) What is the attitude of adult learners towards using ICT?

(3) Are lecturers aware of the importance of using ICT for teaching?

(4) What are the various sources of materials available to adult learners? 


\section{Methodology}

The sample population consists of two hundred respondents .The two hundred respondents are consisting of (100) students and (100) lecturers. The students were randomly selected from three hundred (300) adult learners of the departments of adult education, Osun State Colleges of Education while the lecturers were selected from four hundred (400) lecturers of Osun State Colleges of Education using simple randomization techniques.

The questionnaires were drawn up based on the research questions. The questionnaire comprised of five (5) sections: A, B, C, D, and E. Section A is designed to collect demographic information about the respondents. Section $\mathrm{B}$ focused on information about the availability of ICT facilities for teaching and learning. Section $\mathrm{C}$ seeks to collect detailed information about their attitude towards the use of ICT. Section D gathers data on lecturers' awareness of the importance of ICT for teaching while section E concerns itself to finding out the various sources of ICT equipments available for teaching and learning. Sections D and E are exclusively reserved for the lecturers, thereby excluding the students, based on the nature of information in the sections though, this is a calculative attempt to get a valid response. The questions were reacted to and percentages were adopted to analyze the data.

\section{Results}

Research Question 1: Which of these ICT facilities are available for teaching and learning?

From table 1 displaying the availability of ICT facilities for teaching and learning, it is shown that $54 \%$ of the respondents indicated that computers are available for teaching and learning while $45 \%$ disclaimed its availability. $45 \%$ of 200 respondents concurred that overhead projector/Power Point presentation is available while $55 \%$ of them indicated that such facility is not available. $18 \%$ of the respondents suggested that videos are available for use in learning and teaching while the remaining $82 \%$ indicated that they are not available for teaching and learning. Also from the table above, $54 \%$ of the respondents pointed to the fact that internet connected computers are available for teaching and learning while $46 \%$ of them moved in the opposite direction, asserting that such facility is not available for both teaching and learning. $40 \%$ of the respondents pointed out that CD Roms are available for educational purpose while $60 \%$ opined that CD Roms are not available for 
such purpose. Database software is said to be available for teaching and learning by $36 \%$ of the respondents while $64 \%$ of them indicated 'NO'. The general assessment showed that most ICT facilities are of not adequately available.

Research Question 2: What is the attitude of lecturers and adult learners towards the use of ICT?

From table 2, it is shown that $81 \%$ of the respondents agreed that they use computer only when it is absolutely necessary in their work/study; $5 \%$ were not sure while $14 \%$ of the respondents disagreed. $91 \%$ agreed that using computer does not scare them while $3 \%$ of the respondents expressed their feeling towards the use of computer as scaring them and $6 \%$ were not sure as to whether or not they are scared. Still from the table above. $73 \%$ agreed that they do not feel apprehensive about using computer. Though, $8 \%$ were not sure, $19 \%$ pointed out that they feel apprehensive about using computer. $17 \%$ revealed that they avoid coming into contact with computers in their works. $2 \%$ of them were not sure while the remaining $81 \%$ showed absolute disagreement with this assertion, indicating that they do not avoid the computers in their works. $86 \%$ affirmed that they never worry about looking stupid whenever they use the computer while $10 \%$ of them did not hide their feeling, showing that they worry whenever they use computer that they might look stupid. $4 \%$ of them were undecided. $9 \%$ agreed that they hesitate using the computer for the fear of making mistake, $6 \%$ were not sure while $85 \%$ did not agree with the notion. Also, $69 \%$ did not agree that they can do most things that the computer can be used for while $15 \%$ of them agreed that they can most things that the computer can used for. $16 \%$ were not sure. $81 \%$ of the respondents suggested that they can make the computer do what they want it to do; $8 \%$ were not sure whether they can or not while the remaining $11 \%$ stated that they cannot make the computer do what they want it to do. Exactly $95 \%$ of the respondents confirmed that the computer the computer avail them the opportunity of doing more interesting and imaginative works while $2 \%$ declined and $3 \%$ were not sure. $83 \%$ agreed that they will use the computer regularly throughout their work life while $12 \%$ of them disagreed with $5 \%$ of them not sure.

From the information presented above, conclusion can be made that both lecturers and students have positive attitude towards the use of Information and Communication Technology. 
Research Question 3: Are lecturers aware of the importance of using ICT for teaching?

From table 3 it is shown that $86 \%$ of the respondents are aware that search for information on the World Wide Web (WWW) is very important and important as indicated by $10 \%$ of the respondents while $4 \%$ of them showed that is not important. Creating web pages is indicated as being very important by $34 \%$ of the respondents; $36 \%$ of them also showed that it is important while $30 \%$ indicated that it is not important. $8 \%$ of the respondents suggested that using database is not important while $34 \%$ and $58 \%$ of respondents pointed out that it is very important and important respectively. Also, 22\% of respondents revealed that developing database is not important. $32 \%$ said it is very important and $46 \%$ indicated 'important'. $46 \%$ of respondents indicated that writing a programme is very important and $24 \%$ showed it is important while $28 \%$ of them showed that it is not important. Using an instructional programme (including simulation) is indicated as very important by $36 \%$ of respondents and important by $38 \%$ of them while the remaining $26 \%$ declined that using such a programme is important. $52 \%$ of respondents also revealed that presenting information using PowerPoint is very important; $32 \%$ showed that it is important while $16 \%$ suggested that it is not. Writing paper with word processing is regarded by $52 \%$ of the respondents as very important while $38 \%$ just pointed out that is important but $10 \%$ did not agree showing that it is not important. Also, $22 \%$ of respondents showed that drawing picture or diagram with graphing/drawing application is not important while $42 \%$ of respondents affirmed that drawing picture or diagram with graphing/drawing application is very important while $36 \%$ of respondents said that it is important and $22 \%$ of the respondents said it is not important. $40 \%$ of respondents indicated 'very important'; $42 \%$ indicated 'important' while $18 \%$ indicated 'not important (at all)' for using computer with slide projector for teaching and learning.

The overall assessment from the above analysis revealed that lecturers are very well aware of the importance of Information and Communication Technology (ICT) in teaching and learning.

Research question 4: What are the various sources of ICT materials available for teaching and learning?

From table 4 , it is shown that $42 \%$ of the respondents agreed that the government supply of ICT equipment is low, $50 \%$ agreed that the supply is totally nil while $8 \%$ of them agreed that the supply is sufficient. $44 \%$ of the 
respondents indicated that non-governmental organisations (NGO) do not fund ICT equipment, while $34 \%$ of them agreed that the fund supply is low and $22 \%$ that NGOs do supply the department with ICT equipments. $52 \%$ of the respondents indicated that the alumni body of their department do not supply fund for ICT equipments while $22 \%$ of them agreed that they supply very low fund for ICT equipments with $26 \%$ of the respondents asserting that alumni body of their department do supply them with ICT equipment.

$56 \%$ of the respondents disagreed the funding of ICT equipment by the student association of the department, $22 \%$ of them agreed that the supply is low while $22 \%$ indicated sufficient supply. $48 \%$ of the respondents indicated that the university from her income does not fund ICT equipment acquisition: $34 \%$ of them agreed that the supply is low while $18 \%$ indicated sufficient supply. $48 \%$ of the respondents indicated that they do not get money by raising fund from important dignitaries in the country; $32 \%$ of them revealed that the money raised from important dignitaries in the country is low while $20 \%$ of them indicated sufficient funding. 46\%; 50\%; and $60 \%$ of the respondents disagreed receiving any fund from company/industries, international bodies and organizations and by liaising with any university abroad respectively while $22 \%$; $38 \%$; and $26 \%$ of the respondents indicated that they receive low support with $32 \% ; 12 \%$ and $14 \%$ indicating sufficient supply. The total assessment from the analysis above showed that there are inadequate and insufficient supplies of ICT equipments and its funding.

\section{Conclusion}

From the results of the research work, the following conclusions were made: The institution should embark on series of programmes such as award giving to raise funds from important dignitaries in the country. Government should endeavor to supply necessary funds for the acquisition of relevant ICT equipment. The institution should also find proper medium of liaising with other institution abroad as an affiliate in running information technology programmes for proper support and involve bodies such as NonGovernmental Organizations (NGO), companies and industries, and alumni body in funding ICT equipment acquisition projects. The available fund realized from appropriate quarters must be managed properly and ensured that is used for funding the acquisition of required ICT equipment and distribution to various faculties and departments should be done appropriately. In-service computer training should be given to all the staff 
including the management and Fresh students should be given basic ICTknowledge immediately.

\section{References}

Adekomi, A. A. (2006). The Use of Internet in the teaching of Adults. Ondo: MacMillan.

Becker, H. J. (2000). "Pedagogical Motivations for Student Computer Use that Leads to Student Engagement". Education Technology. Vol. 40, no. 5 , pp. 5-17.

Ben, Y., Dahmani, M. (2008). "The Impact of ICT on Student Performance in Higher Education: Direct Effects, Indirect Effects and Organizational Change". In: "The Economics of E-learning" [online monograph]. Revista de Universidady Sociedad del Conocimiento (RUSC). Vol. 5, no. 1. UOC. [Accessed: 08/03/2008]. http://www.uoc.edu/rusc/5/I/dt/eng/benyoussef_dahmani.pdf.

Conlan, J., Grabowski, S., \& Smith, K. (2003). Adult Learning. In Orey. M. (Ed.), Emerging perspectives on learning, teaching, and technology. Retrieved <0ctober 5, $2008>$, from http://projects.coe.uga.edu/epltt/

Conner, M. L. (2004). 'Andragogy and Pedagogy', Ageless Learner, http://agelesslearner.com/intros/andragogy.htm. May 5,2008.

Cox M, Webb M, Abbott C, Blakeley B, Beauchamp T, Rhodes V, Watson D, Turnbull M (2003). ICT and Pedagogy - A Review of the Research Literature. ICT in Schools Research and Evaluation series. Coventry: Becta. www.becta.org.uk/research.

Courtney, S. (1989) 'Defining Adult and Continuing Education' in Merriam, S. B. and Cunningham, P. M. (eds.) Handbook of Adult and Continuing Education, San Francisco: Jossey-Bass.

Dubin, S. S. and Okun, M. (1973). Implications of Learning Theories for Adult Instruction. Adult Education, 24 (1), pp. 1-15.

EPPI (2003). A Systematic Review of the Impact on Students and Teachers of the Use ofICT for Assessment of Creative and Critical Thinking Skills.Review conducted by the Assessment and Learning Research 
Synthesis Group, Evidence for Policy and Practice (EPPI) Centre. July 2003. http://eppi.ioe.ac.

Fuchs, T. and Woessmann, L. (2004). "Computers and Student Learning: Bivariate and Multivariate Evidence on the Availability and Use of Computers at Home and at School", CESifo Working Paper. No. 1321. November. Munich.

Goldberg, A., Russell, M., and Cook, A. (2003). The Effect of Computers on Student Writing: A meta-Analysis of Studies from 1992 to 2002. Journal of Technology, Learning, and Assessment, 2.1, pp 1-52 (Available from http://www.jtla.org).

Higgins, S. and Moseley, D. (2001). Teachers' Thinking about ICT and Learning: Beliefs and Outcomes. Teachers' Development 5.2, pp. 191-210.

Jonassen D. H. (1991). Evaluating Constructivist Learning. Educational Technology, 31 (9), pp. 28-33.

Jonassen, D. H. (2000). Computers as Mind Tools for Schools: Engaging Critical Thinking. 2ed.New Jersey: Prentice Hall.

Knowles, M. (1970). The Modern Practice of Adult Education. New York: Association Press.

Knowles, M. (1984). Andragogy in Action. San Francisco: Jossey-Bass.

Knowles, M. (1984). The Adult Learner: A Neglected Species (3rd Ed.). Houston. TX: Gulf Publishing.

Kulik, J. A. (1994). "Meta-analysis Study of Findings on Computer-based Instruction". In: baker: E. L. \& O'neil, H. F. Technology Assessment in Education and Training. Hillsdale, NJ: Lawrence Eribaum

Lawler, P.A. \& King, K.P. (2003). Changes, Challenges, and the Future. New Directions for Adult and Continuing Education, v. 98, p. 83-91.

Newhouse C.P. (2002). The Impact of ICT on Learning and Teaching.

Literature review. Western Australian Department of Education. www.eddept.wa.edu.au

Newhouse, C.P., Trinidad, S., and Clarkson, B. D. (2002). Quality Pedagogy and Effective Learning with Information and Communications 
African Research Review Vol. 3 (5), October, 2009. Pp.275-289

Technologies (ICT): A Review of the Literature. Perth,Western Australia: Specialist Educational Services Eduard C. Lindeman (1926). The Meaning of Adult Education. New York: New Republic.

Rudd P. (2000). School Improvement through ICT: Limitations and Possibilities. Paper presented at European Conference on Educational Research (ECER) University of Edinburgh, 22nd September 2000.

Sandholtz, M. (2001).Information Technology and You. U.S.A.: Macmillan.Smith.

M. K. (1996; 1999) 'Andragogy', The Encyclopaedia of Informal Education.

http://www.infed.org/lifelongleaming/b-andra.htm.

$\begin{array}{lll}\text { September } 25, & 2008\end{array}$

http://www.nestafuturelab.org/reviews/ts01 .htm

http: www.nl.edu/academics/cas/ace/resources malcolmknowles.cfm

http:www. becta.org.uk/research/reports/ictresources.cfm 
Table 1: ICT facilities

\begin{tabular}{|l|l|l|l|l|l|}
\hline S/N & FACILITIES & YES & $\%$ & N0 & $\%$ \\
\hline 1. & Computers & 220 & $55 \%$ & 80 & $45 \%$ \\
\hline 2. & $\begin{array}{l}\text { Overhead } \\
\text { Projector/PowerPoint }\end{array}$ & 180 & $45 \%$ & 220 & $55 \%$ \\
\hline 3. & Videos & 72 & $18 \%$ & 228 & $82 \%$ \\
\hline 4. & Internet connected computer & 216 & $54 \%$ & 484 & $46 \%$ \\
\hline 5. & CD Rom & 160 & $40 \%$ & 40 & $60 \%$ \\
\hline 6. & Database software & 144 & $36 \%$ & 56 & $64 \%$ \\
\hline
\end{tabular}

Table 2: Attitude of lecturers and adult learners towards the use of ICT

\begin{tabular}{|l|l|l|l|l|l|l|l|}
\hline S/N & $\begin{array}{l}\text { ATTITUDE TOWARDS } \\
\text { THE USE OF ICT }\end{array}$ & AGREE & $\%$ & $\begin{array}{l}\text { NOT } \\
\text { SURE }\end{array}$ & $\%$ & $\begin{array}{l}\text { DIS- } \\
\text { AGREE }\end{array}$ & $\%$ \\
\hline 1. & $\begin{array}{l}\text { I use computer in my study } \\
\text { only when it is absolutely } \\
\text { necessary }\end{array}$ & 162 & $81 \%$ & 10 & $5 \%$ & 28 & $14 \%$ \\
\hline 2. & $\begin{array}{l}\text { Using computer does not scare } \\
\text { me at all }\end{array}$ & 182 & $91 \%$ & 12 & $6 \%$ & 6 & $3 \%$ \\
\hline 3. & $\begin{array}{l}\text { I don't feel apprehensive about } \\
\text { using computer }\end{array}$ & 146 & $73 \%$ & 16 & $8 \%$ & 38 & $19 \%$ \\
\hline 4. & $\begin{array}{l}\text { I avoid coming into contact } \\
\text { with computers in my work }\end{array}$ & 34 & $17 \%$ & 4 & $2 \%$ & 162 & $81 \%$ \\
\hline 5. & $\begin{array}{l}\text { When I use computer, I worry } \\
\text { that I might look stupid }\end{array}$ & 20 & $10 \%$ & 8 & $4 \%$ & 172 & $86 \%$ \\
\hline 6. & $\begin{array}{l}\text { I hesitate using a computer for } \\
\text { the fear of making mistake }\end{array}$ & 18 & $9 \%$ & 12 & $6 \%$ & 170 & $85 \%$ \\
\hline 7. & $\begin{array}{l}\text { Most things that a computer } \\
\text { can be used for, I can do just as } \\
\text { well myself }\end{array}$ & 30 & $15 \%$ & 32 & $16 \%$ & 138 & $69 \%$ \\
\hline 8. & $\begin{array}{l}\text { I can make the computer do } \\
\text { what I want it to do }\end{array}$ & 81 & $81 \%$ & 8 & $8 \%$ & 11 & $11 \%$ \\
\hline 9. & $\begin{array}{l}\text { Computers can allow me to do } \\
\text { more interesting and } \\
\text { imaginative work }\end{array}$ & 95 & $95 \%$ & 3 & $3 \%$ & 2 & $2 \%$ \\
\hline 10. & $\begin{array}{l}\text { I will use computers regularly } \\
\text { throughout my work life }\end{array}$ & 83 & $83 \%$ & 12 & $12 \%$ & 5 & $5 \%$ \\
\hline
\end{tabular}


Table 3: Lecturers awareness of the importance of ICT

\begin{tabular}{|c|c|c|c|c|c|c|c|}
\hline $\mathbf{S} / \mathbf{N}$ & HOW IMPORTANT & $\begin{array}{l}\text { VERY } \\
\text { IMPOR } \\
\text { TANT }\end{array}$ & $\%$ & $\begin{array}{l}\text { IMPOR- } \\
\text { TANT }\end{array}$ & $\%$ & & $\begin{array}{l}\text { \% } \\
\text { RTANT }\end{array}$ \\
\hline 1. & $\begin{array}{l}\text { Search for information } \\
\text { on the } \\
\text { World Wide Web }\end{array}$ & 86 & $86 \%$ & 10 & $10 \%$ & 4 & $4 \%$ \\
\hline 2. & Creating web pages & 34 & $34 \%$ & 36 & $36 \%$ & 30 & $30 \%$ \\
\hline 3. & Using Database & 34 & $34 \%$ & 58 & $58 \%$ & 8 & $8 \%$ \\
\hline 4. & Developing a Database & 32 & $32 \%$ & 46 & $46 \%$ & 22 & $22 \%$ \\
\hline 5 . & Writing a programme & 46 & $46 \%$ & 24 & $24 \%$ & 28 & $28 \%$ \\
\hline 6. & $\begin{array}{l}\text { Using an instructional } \\
\text { programme } \\
\text { (including simulation) }\end{array}$ & 36 & $36 \%$ & 38 & $38 \%$ & 26 & $26 \%$ \\
\hline 7. & $\begin{array}{l}\text { Presenting information } \\
\text { (e.g using power point) }\end{array}$ & 52 & $52 \%$ & 32 & $32 \%$ & 16 & $16 \%$ \\
\hline \multirow[t]{2}{*}{8.} & Writing paper with word & 52 & $52 \%$ & 38 & $38 \%$ & 10 & $10 \%$ \\
\hline & processing & & & & & & \\
\hline \multirow[t]{2}{*}{9.} & $\begin{array}{l}\text { Drawing picture or } \\
\text { diagram with }\end{array}$ & 42 & $42 \%$ & 36 & $36 \%$ & 22 & $22 \%$ \\
\hline & $\begin{array}{l}\text { graphing/drawing } \\
\text { application }\end{array}$ & & & & & & \\
\hline 10. & $\begin{array}{l}\text { Using computer with } \\
\text { slide projector for } \\
\text { teaching and learning }\end{array}$ & 40 & $\begin{array}{l}40 \\
\%\end{array}$ & 42 & $\begin{array}{l}42 \\
\%\end{array}$ & 18 & $\begin{array}{l}18 \\
\%\end{array}$ \\
\hline
\end{tabular}

Table 4: Various sources of ICT materials

\begin{tabular}{|c|l|c|c|c|c|c|c|}
\hline S/N & \multicolumn{1}{|c|}{ SOURCES } & $\begin{array}{l}\text { VERY } \\
\text { WELL }\end{array}$ & $\%$ & LOW & \% & $\begin{array}{c}\text { NOT AT } \\
\text { ALL }\end{array}$ & \% \\
\hline 1. & $\begin{array}{l}\text { Government does } \\
\text { supply the ICT } \\
\text { equipment for our } \\
\text { department as fund or } \\
\text { property. }\end{array}$ & 8 & $8 \%$ & 42 & $42 \%$ & 50 & $50 \%$ \\
\hline
\end{tabular}




\begin{tabular}{|c|c|c|c|c|c|c|c|}
\hline 2. & $\begin{array}{l}\text { Some Non- } \\
\text { Governmental } \\
\text { Organizations do } \\
\text { supply ICT equipment } \\
\text { for our department. }\end{array}$ & 22 & $22 \%$ & 34 & $34 \%$ & 44 & $44 \%$ \\
\hline 3. & $\begin{array}{l}\text { Alumni body of our } \\
\text { department do supply } \\
\text { us ICT equipment } \\
\text { fund. }\end{array}$ & 26 & $26 \%$ & 22 & $22 \%$ & 52 & $52 \%$ \\
\hline 4. & $\begin{array}{l}\text { Student association of } \\
\text { the department do } \\
\text { supply us ICT } \\
\text { equipment fund }\end{array}$ & 22 & $22 \%$ & 22 & $22 \%$ & 56 & $56 \%$ \\
\hline 5. & $\begin{array}{l}\text { University from her } \\
\text { income reserve do } \\
\text { supply us ICT } \\
\text { equipment fund }\end{array}$ & 18 & $18 \%$ & 34 & $34 \%$ & 48 & $48 \%$ \\
\hline 6. & $\begin{array}{l}\text { We do get the money } \\
\text { by raising fund from } \\
\text { important dignitaries } \\
\text { in } \\
\text { the country. }\end{array}$ & 18 & $20 \%$ & 32 & $32 \%$ & 48 & $48 \%$ \\
\hline 7. & $\begin{array}{l}\text { Some company } \\
\text { industries and the likes } \\
\text { do supply us ICT } \\
\text { equipment } \\
\text { Fund }\end{array}$ & 32 & $32 \%$ & 22 & $22 \%$ & 46 & $46 \%$ \\
\hline $\mathbf{S} / \mathbf{N}$ & SOURCES & $\begin{array}{l}\text { VERY } \\
\text { WELL }\end{array}$ & $\%$ & LOW & $\%$ & $\begin{array}{c}\text { NOT AT } \\
\text { ALL }\end{array}$ & $\%$ \\
\hline 8. & $\begin{array}{l}\text { International bodies } \\
\text { and organizations do } \\
\text { supply us ICT } \\
\text { equipment fund as an } \\
\text { aid }\end{array}$ & 12 & $12 \%$ & 38 & $38 \%$ & 50 & $50 \%$ \\
\hline 9. & $\begin{array}{l}\text { We do get the supply } \\
\text { of ICT equipment fund } \\
\text { by liaising with } \\
\text { some other } \\
\text { universities abroad }\end{array}$ & 14 & $14 \%$ & 26 & $26 \%$ & 60 & $60 \%$ \\
\hline
\end{tabular}

